\title{
17. Atasözlerinde yönelim metaforları
}

\section{Betül BÜLBÜL OĞUZ1}

APA: Bülbül Oğuz, B. (2021). Atasözlerinde yönelim metaforları. RumeliDE Dil ve Edebiyat Araştırmaları Dergisi, (23), 259-273. DOI: 10.29000/rumelide.948337.

\section{$\ddot{\mathbf{O z}}$}

$\mathrm{Bu}$ çalışmada Türkçede kullanılan atasözlerindeki yönelim metaforları dilbilimsel olarak açıklanarak, Türk düşüncesindeki uzay-mekân kavramlaştırmasının detaylarının ortaya konması amaçlanmıştır. Metafor genel olarak, bir kavramın bir diğerine göre anlam kazanması, bir şeyi başka bir şeye göre düşünmek olarak tanımlanmaktadır. George Lakoff ve mark Johnson'un ortaya koyduğu metafor teorisine göre metaforlar 3 başlık altında ele alınmıştır. Bunlar; 1-Kavramsal (Yapı) metaforlar, 2- Ontolojik (Varlık) metaforlar ve son olarak yönelim metaforlarıdır. Sonuncu başlık olan Yönelim metaforları, bu kavramlaştırma dünyasında; yukarı-aşağı, içeri-dışarı, ön-arka, beri-öte, derin-satıh gibi karşılaştırma ve zıtlıklarla, kullanıldı̆̆ı dildeki merkez ve çevre ilişkisine odaklanmaktadır. Atasözleri ve metaforların kesiştikleri nokta ise kültürlere göre farklılık göstermeleri ve söz konusu kültüre göre kurulan benzerlikleri kullanarak kısa ve öz anlatıma sahip olmalarıdır. Böylelikle; dilde var olan sözcüklerin başka anlam evrenleri ile ilişkilendirilerek kullanılması metaforları ve metaforlar ile kurulmuş atasözleri ise toplumsal belleği yüzyıllar boyunca taşıyabilmektedir. Ayrıca metaforlar her ne kadar doğal dildeki kelimeler ile üretilseler de onlardan farklı olarak nedensiz değillerdir. Bu kapsamda; Türkçede kullanılan atasözlerinde yönelim metaforlarında yukarıda sayılan yönelim kavramlarının; "iyi, kötü, başarılı, başarısız, mutlu, mutsuz, sağlıklı, sağlıksız” gibi hangi kavramlarla eşleştirildiği ve ifade edilmek istenen düşüncenin atasözlerine nasıl yansıdığı makale kapsamında ele alınmıştır. Çalışmada Türkçede kullanılan atasözlerinde bireyin kendisine ve kendisine ait gördüğü çevreyi nasıl normlaştırdığı ve bunlara ilişkin sınırı hangi kelime ve kavramlarla işaretlediği de ortaya konmuştur.

Anahtar kelimeler: Dilbilim, atasözleri, metafor, yönelim metaforları

\section{Orientational metaphors in proverbs}

\begin{abstract}
The aim of this study is to linguistically explain orientation metaphors used in Turkish proverbs and to lay bare the details of time-space conceptualisation in Turkish thought. Generally speaking, metaphor is defined as a concept acquiring meaning through another; in other words, it denotes thinking of something through another thing. Metaphors have been handled under 3 headings according to the metaphor theory presented by George Lakoff and Mark Johnson. These; 1Conceptual Metaphors, 2- Ontological Metaphors and finally Orientational Metaphors. In this conceptualisation, orientation metaphors focus on the centre/periphery relationship within language in which such binaries as up/down, inside/outside, front/behind, here/there and deep/surface are utilised. Proverbs and metaphors intersect on the grounds that both vary throughout cultures and both are precise and short using culture-bound similarities. Also, although
\end{abstract}

Dr. Öğr. Üyesi, Manisa Celal Bayar Üniversitesi, Fen Edebiyat Fakültesi, Türk Dili ve Edebiyatı Bölümü (Manisa, Türkiye), betul.oguz.@cbu.edu.tr, ORCID ID: 0ooo-0002-6743-6293 [Araştırma makalesi, Makale kayıt tarihi: 22.04.2021-kabul tarihi: 20.06.2021; DOI: 10.29000/rumelide.948337]

Adres $\mid$ Address

RumeliDE Dil ve Edebiyat Araşttrmaları Dergisi $\quad$ RumeliDE Journal of Language and Literature Studies Osmanağa Mahallesi, Mürver Çiçeği Sokak, No:14/8 Osmanağa Mahallesi, Mürver Çiçeği Sokak, No:14/8

Kadıköy - İSTANBUL / TÜRKIYE 34714 Kadıköy - ISTANBUL / TURKEY 34714 e-posta: editor@rumelide.com

e-mail: editor@rumelide.com,

tel: +90 505 7958124, +90 2167730616 phone: +90 505 7958124, +90 2167730616 


\begin{abstract}
metaphors are produced with words in natural language, they are arbitrary reason, unlike them. As such, using already existing words in relation to other meaning universes form metaphors; and metaphors in return construct proverbs which do carry social memory. In this respect, this article investigates to which concepts such as "good - bad, successful - unsuccessful, healthy - unhealthy, happy, and unhappy" the aforementioned metaphors used in Turkish proverbs correspond; it also examines how the idea to be expressed is reflected in these proverbs. In the proverbs used in Turkish, the study also revealed how the individual normalizes the environment he considers himself and his own, and what words and concepts mark the limit related to them.
\end{abstract}

Key words: Linguistics, proverbs, metaphor, orientation metaphors

\title{
Giriş
}

Atasözleri ait olduğu kültürün belleği olma niteliği taşımaktadır. Sözlü bir gelenek üzerinden nesilden nesile aktarılan atasözleri; çoğu zaman basit, düz, kolay anlaşılır cümlelerdir. Ancak gramatikal olarak cümle şeklinde tanımlanan bu gramer yapıları kullanıldıkları dilin kültürüne, coğrafyasına ve düşünce dünyasına dair bilgiler ile harmanlanmıştır. Yaylagül bir çalışmasında atasözlerini “...metaforlar üzerine kurulmuş halk cümleleri” (Yaylagül, 2010: 113) şeklinde tanımlamaktadır. Bu tanım, atasözlerinin kendi içinde ontolojik olarak barındırdığı kültürel bellek olmak özelliklerinin altını çizmektedir. Ne zaman ortaya çıktığı bilinmeyen, geçmişten itibaren kullanılagelen atasözleri; az sözle çok şey anlatmaktadır. Bu durum Ömer Asım Aksoy’un bir makalesinde çerçevesini çizdiği şekliyle şekil özellikleri arasında sayılmaktadır. Aksoy makalesinde atasözlerinin şekil özelliklerini; 1kalıplaşmış (klişe hâline gelmiş) sözler, 2-kısa ve özlü olmaları ve son olarak yapısal olarak çoğunlukla iki cümle oluşmaları şeklinde özetlemektedir. Yine aynı makalede atasözlerinin sosyal olayların nasıl gerçekleştiği, tabiat olaylarının nasıl olageldiğini anlatması, ders ve öğüt verme özelliği taşımalarını, adet, gelenek ve inanışları bildirmeleri ise kavramsal özellik olarak tanımlanmıştır (Aksoy, 1988). Atasözleri çizilen bu yapısal ve kavramsal çerçevede kısa cümlelerle zaman zaman iyi ve doğru olan gösterilirken, zaman zaman ise kaçınılması gereken durumlar veya dikkat edilmesi gereken şeyler benzetmeler ve metaforlar kullanılarak anlatılmaktadır.

Bir dilde kullanılan metaforlar ise söz konusu toplumun kültüründen, coğrafyasından ve toplumsal deneyimlerinden beslenmektedir. Bu sebeple; insanoğlunun dünyayı anlama ve algılama yolunda icat ettiği metaforlar ait olduğu kültürün, toplumun ve dil birliğinin kodlarını taşır" (Özevren, 2018: 71). Bu dilsel kodlar sık kullanılmalarına rağmen değişmemiş ve insanlar arasında kurulan iletişimde kullanışlı bir kalıp olarak kalmıştır.

İletişim kurarken, vericinin alıcıya aktarmak istediği mesajın anlaşılır olması gerekmektedir. İletişim açısından bakıldığında bu durum kod ve kodun çözülmesi olarak tanımlanmaktadır. Alıcı ve verici arasında kurulan iletişimde her iki taraf da aynı dilsel kodu paylaşabiliyorlarsa kod çözülebilir. Başka bir değişle alııı ve verici arasındaki kodlar çözülemediğinde iletişimi gerçekleşmemektedir (Kıran Kıran, 2006: 81-90). Gündelik dilde sıklıkla kullanılan söz kalıpları, deyimler, ikilemeler gibi dil yapıları hem iletişimi kolaylaştırmaya elverişlidirler hem de yukarıda da belirtildiği gibi kısa anlatımla ekonomik bir anlatım imkânı sunmaktadır. Atasözleri de bu yapıların içerisinde toplumsal olarak kabul görmüş bir iletişim öğesi olarak yer almaktadır. Bu sebeple herhangi bir konuda iletişim kurulurken kullanılan bir atasözü en az çaba ile çok sayıda mesajı karşı tarafa iletebilmektedir. Atasözlerinin bir cümle ile istenilen bağlamdaki mesajı iletebilmesinde metaforik anlatıma sahip olmalarının payı büyüktür.

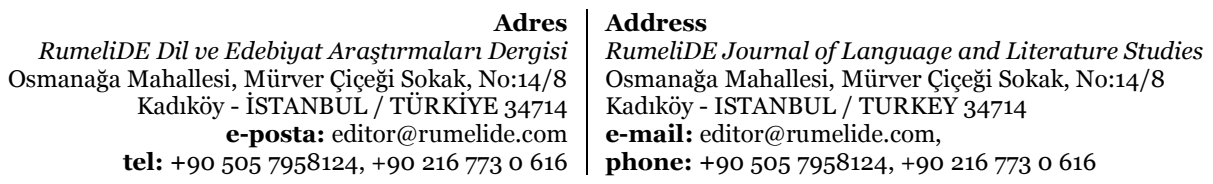


Son yıllarda hem metafor teorisi kullanılarak hazırlanan makaleler hem de atasözleri ve deyimlere metaforik açıdan bakılan araştırmaların arttığını söylemek mümkündür. Çalışma kapsamında bu kapsamdaki yayınlardan da faydalanılmaya çalışılmıştır. Ayrıca, bu çalışmada Ömer Asım Aksoy’un yayınladığı Atasözleri kitabı ana kaynak olarak kullanılmıştır. Makale içerisindeki örnekler söz konusu eserin taranması ile oluşturulmuştur.

\section{Metaforlar ve atasözleri}

Metafor (metaphore) kelimesi sonra, ile anlamındaki meta ve ve söz aktarmak, nakletmek anlamlarını taşıyan fora (phora) kelimelerinden oluşmaktadır. Türkçesi eğretileme olan metafor bir şeyi başka bir şeye taşımayı ifade etmek için kullanılmaktadır. Eski çağlardan beri bir söz sanatı olarak kullanılan metafor kavramı Aristoteles’in Poetika isimli eserinde "bir sözcüğe, kendi özel anlamının dışında bir anlam verilmesi” şeklinde tanımlanmıştır (Aristoteles 2004: 21). Modern anlamda en kapsamlı metafor kaynağı olarak George Lakoff ve Mark Johnson’un yazdığı metafor teorisi gösterilmektedir. Bu teoride Lakoff ve Johnson'ın metaforların özelliklerini sayarken söz ettikleri sosyal, kültürel ve/ veya kişisel deneyimlerin (Lakoff-Johnson 2005: 25) önemi atasözleri ve metaforları birleştiren bir başka durum olarak karşımıza çıkmaktadır.

Metafor sadece dilde değildir; düşünmede ve eylemde kullanılan kavramsal sistemlerin temelde metaforik bir doğası vardır. Yani çağdaş metafor incelemesi metaforu bir düşünce malzemesi, insan kavrayışının bir şekli olarak ve sadece bir söz figürü değil aynı zamanda bir 'düşünce figürü' olarak görmektedir.

Lakoff ve Johnson kavramsal metafor (metaforik kavram, bilişsel metafor) ile dilsel metaforu (metaforik ifade) birbirinden ayırmıştır. Kavramsal metaforlar soyut fikirlerdir. Mesela "Vakit nakittir" bir kavramsal metafordur; yani insanlar zamanı para ile birlikte kavramlaştırmıştır. Bu tip metaforlar dünyayı kavrayış şekli ile ilgilidir. Dilsel metaforlar ise bu soyut fikirleri gerçekleştiren, hayata geçiren, dildeki ifadelerdir. Mesela "Vaktini iyi harcamalısın" sözü, "Vakit nakittir" kavramsal metaforunun dildeki bir örneğidir; bir dilsel metafordur. Bir başka deyişle dildeki metaforik ifadeler, metaforik kavramların yüzeydeki bildirimleridir.

Metaforlar, anlaşılması zor kavramların benzetme yoluyla bilinen kavramlarla anlatılması olarak resmi ve resmi olmayan öğrenmelerde de karşımıza çıkmaktadır. Metaforlar, insanların hayatı, çevreyi, olayları ve nesneleri nasıl gördükleri; farklı benzetmeler kullanarak açıklamaya çalışmada kullandıkları bir araç olarak düşünülmektedir (Cerit 2008: 694).

Soyut düşünce ve metafor hayal gücünün merkezinde yer alan ve düşüncenin önemli bir kaynağı olan (Modell 2009) metafor, soyutla somutun birlikte oluştuğu bir zihinsel düzey olarak görülebilir. Hayal etmeyi sağlayan zihinsel şema bir taraftan soyut önermeler diğer taraftan somut betimlemeler sunan bir zihinsel düzenleme şeklinde çalışır (Johnson 1987). Soyut kavramlar yaşantılar sonucunda oluşan somut görüntülerin yer aldığı şemalar aracılığıyla da anlaşılmaktadır (Lakoff 1990).

Bir diğer deyişle, metaforik kavrayış temel olarak yaşantının içinde somutlaşmaktadır (Amin 2009). Model (2009) metaforu yaşantılarla çalışırken kullanılabilecek vazgeçilmez bir araç olarak görmekte; bu sebeple metaforik betimlemeleri ortaklaşa yaşanmamış deneyimlerin karşı tarafa aktarılmasında çok önemli beceri olarak tanımlanmaktadır (Lakoff ve Johnson 1980).

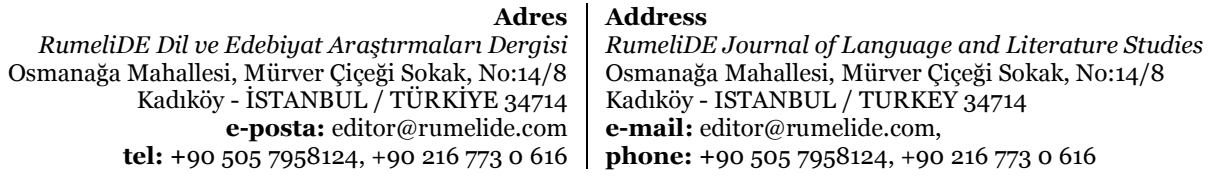

RumeliDE Dil ve Edebiyat Araştırmaları Dergisi e-posta: editor@rumelide.com tel: +90 $5057958124,+902167730616$
Address

Osmană̆

e-mail: editor@rumelide.com

phone: +90 5057958124, +90 2167730616 
Metafor görsel ve somut betimlemeler ileterek anlamın dinleyen tarafta canlı ve belirgin olmasina yardım etmekte; böylece dinleyicide yaşantısal bir tepki oluşturmaktadır (Shinebourne ve Smith 2010).

Yani sonuç olarak; ne kadar soyut bir dil kullanırsak anlaşılmamız da o derece zor olacaktır. Bu yüzden karşıdaki kişinin bizi daha iyi dinleyip anlayabilmesi için metaforlarla anlatmaya çalışırız ve böylece düşüncemizi somutlaştırmış ve karşıdaki alıcının daha iyi anlayabileceği dikkatini çekebileceği bir duruma getirmiş oluruz.

Lakoff ve Johnson metaforları üç başlık altında incelemişlerdir. Bunlar;

1-Kavramsal (Yapı) Metaforlar (Conceptual Metaphors)

2-Ontolojik (Varlık) Metaforlar

3-Yönelim Metaforları (Orientational Metaphors)

Kavramsal metaforlarda metaforun kaynağı ve hedefi olmak durumundadır. Ayrıca Kavramsal metaforlar büyük harflerle gösterilmektedir. Örneğin;

KAYNAK yoksulluk HEDEF hastalık olarak verilebilir. Burada yoksulluk kavramı üzerinden hastalık metaforuyla bir çıkarım yapılmıştır. Bu sebeple Yoksulluğun belirtileri, yoksulluğun yayılması ya da tedavi edilmesi gereken bir durum olarak yoksulluk kavramları kullanılabilmektedir.

Ontolojik metaforlar ise fiziksel nesnelerle, kendi bedenimizle ilgili tecrübelere "yani olaylara, aktivitelere, hislere, düşüncelere" (Lakoff-Johnson 2005: 55) dayanmaktadır. Lakoff ve Johnson bu noktada Zihnin bir makine olduğundan hareketle örnekler sıralamaktadır. Zihnin bir makine olduğu düşünüldüğünde aşă̆gdaki örnekleri sıralamak mümkündür:

Zihnim bugün hiç işlemiyor.

Bugün biraz pas tuttum.

Bütün gün bu problem üzerinde çalıştı ve şimdi pilimiz bitiyor. (Lakoff-Johnson 2005: 55).

\section{Yönelim metaforları}

Yönelim metaforları kullanıldıkları kültürde insan ve evren arasındaki yönelimi ortaya koymaktadır. Merkez - çevre ya da uzay-mekân algısı bu tip metaforların temelini oluşturur. Elbette tüm metaforlar gibi yönelim metaforları da nedensiz değildirler. Bulunulan coğrafya, fiziksel ve kültürel tecrübe bu tip metaforlardaki yönü ve o yönün hangi kavrama karşılık geldiğinde belirleyicidir. "Yukarı-aşağı, içeridışarı, ön-arka, beri- öte, derin-satıh, merkez-çevre” (Lakoff-Johnson 2005: 40) gibi tüm yönelimler bu başlık altında değerlendirilmektedir.

Metafor kullanımı ile soyut olan bir kavramın somutlaştırılması sağlanmaktadır. Bu somutlamada yönelimlerin kullanılması kelimeyi kendi anlam alanından çıkararak başka bir kavram evrenine taşımaktadır.

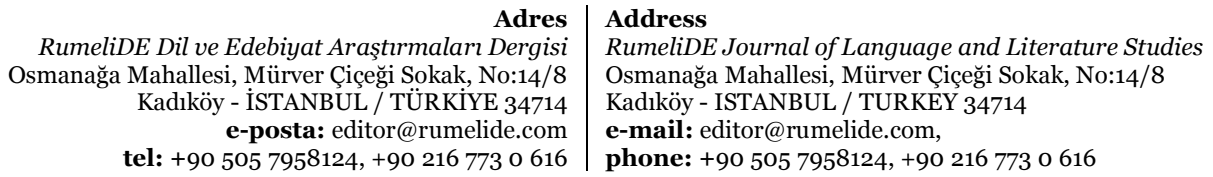

tel: +90 505 7958124, +90 2167730616 


\section{Dikey yönelim bağlamında yukarı aşağı metaforları}

Birçok kültürde olduğu gibi Türklerde de IYYI OLAN YUKARIDADIR metaforu kullanılmaktadır. Kutsal sayılan Tanrı, erişilemez olan ay, yıldız, toplumsal hiyerarşi gereği büyükler için kullanılan ulu sözcüğü gibi örnekler IYİ OLAN YUKARIDADIR metaforunu desteklemektedir. Deyimlerdeki yönelim metaforları üzerine yapılan bir çalışmada da İYI, MUTLU, SAĞLIKLI, GÜÇ SAHİBİ olanının yukarıda olduğunu göstermektedir. "Ayakları yerden kesilmek, elden ayaktan düşmek, el üstünde tutmak, küçük düşmek, yelkenleri suya indirmek” (Sarı 2016: 214) gibi örnekler bu toplumsal kabulü gözler önüne sermektedir.

Yukarı ve aşağı yönelimleri bir metafor olarak ifade edilirken, in-, çık-, bin-, düş-, yıkıl- gibi fillerden sıklıkla yararlanıldığı görülmektedir. Yukarı-aşağı metaforları ister doğrudan bu fiilleri taşıyarak ister de dolaylı olarak olsun yönelim metaforları arasında en sık kullanılan metafor tipleridir.

Lakoff ve Johnson yukarı-aşağı metaforlarında MUTLU OLAN YUKARIDA; KEDERLİ OLAN AŞAĞIDADIR algısının fiziksel bir temele dayandığını belirtmektedir. Bu fiziksel temel; "eğilme tavrı genellikle keder ve depresyona eşlik eder, dik duruş ise pozitif bir duygu durumuna eşlik eder" (LakoffJohnson 2005: 41) şeklinde açlklanmaktadır. "Ah yerde kalmaz" (Aksoy 2013: 125) ve "Hak yerde kalmaz” (Aksoy 2013: 330) atasözleri bu kederli ve olumsuz durumun Türkçe atasözlerindeki göstergelerinden biridir. Yine "söz var dağa çıkarır; söz var dağdan indirir" (Aksoy 2013: 432) atasözü de insanın refah ve mutluluk içerisinde olmasını; yukarıda olan dă̆ kelimesi ve çı- fiili ile metaforlaştırmıştır.

Hem burada hem de diğer yönelim metaforlarında doğrudan ifade edilmeyen ancak dağ kelimesinde görüldüğü gibi yukarıda olması sebebiyle IYYİ, SAĞLIKLI, MUTLU ya da MUKTEDİR addedilen öğelerden faydalanılmıştır. Güneş de bu öğelerden biridir. SAĞLIK VE HAYAT YUKARIDA; HASTALIK VE ÖLÜM AŞAĞIDADIR yargısından hareketle örnek verilebilecek "Güneş girmeyen eve doktor girer" atasözü bu durum için örnektir. Yukarıda olan sağlıklıdır ve iyidir. Güneş yukarıdadır ve bu sebeple bu örnek oluşturulabilmiştir. Sağlıklı olanın yanı sıra hayat da yukarıdadır. Bu sebeple hastalık ve ölüm ise aşağıdadır. "Az kaz, uz kaz, boyunca kaz" (Aksoy 2013: 171) atasözündeki kazeylemi ile ölümün ve insanın yolunda gitmeyen bir işte ısrar etmesinin mezar metaforu ile karşımıza çıtığı̆ görülmektedir. Benzer bir biçimde; "Kazma elin kuyusunu, kazarlar kuyunu” (Aksoy 2013: 353) insanın zor düşmesi ya da düşürülmesi aşağıda olmakla tasvir edilmiştir.

Yönelim metaforlarının içerisinde yukarı ve aşağı metaforlarının sıklı̆̆ının dikkat çektiği yukarıda belirtilmişti. Bu noktada IYİ OLAN YUKARIDA KÖTÜ OLAN AŞAĞIDADIR argümanının ise yukarıaşağı metaforları arasında sayıca çok olduğunu belirtmek gerekmektedir. İnsanın fiziksel, kültürel deneyimleri ile ortaya çıkan metaforlarda kendini merkeze alması ise dildeki tüm metaforik kullanımlar gibi atasözlerinde de ortaya çıkmaktadır. Baş kelimesi hem bir organ ismi olarak hem de lider, öncü anlamları ile yukarıdadır. Baş kelimesinin kendi anlam alanı metaforik kullanım için çok uygundur. Bu sebeple de sıklıkla kullanıldığı görülmektedir.

\footnotetext{
Dost başa bakar düşman ayağa (Aksoy 2013: 264)

Balık baştan avlanır (Aksoy 2013: 171)

Balık baştan kokar (Aksoy 2013: 178)

Başak büyüdükçe başın eğer (Aksoy 2013: 180)

Başın sağlı̆̆ı dünyanın varlığı. (Aksoy 2013: 182)
}

Adres
RumeliDE Dil ve Edebiyat Araşttrmaları Dergisi
Osmanağa Mahallesi, Mürver Çiçeği Sokak, No:14/8
Kadıköy - İSTANBUL / TÜRKIYY 34714
e-posta: editor@rumelide.com
tel: +90 505 7958124, +90 216 7730616
Address

RumeliDE Journal of Language and Literature Studies

Osmanağa Mahallesi, Mürver Çiçeği Sokak, No:14/8

Kadıköy - ISTANBUL / TURKEY 34714

e-mail: editor@rumelide.com,

phone: +90 505 7958124, +90 2167730616 
Baş olan boş olmaz. (Aksoy 2013: 182)

Baş yarılır börk içinde kol kırılır börk (yen) içinde. (Aksoy 2013: 252)

Baş ol da eşek başı (soğan başı) ol (Aksoy 2013: 185)

Ayağını sıcak tut başını serin; gönlünü ferah tut düşünme derin. (Aksoy 2013: 166)

Ayağı yürüten baştır. (Aksoy 2013: 166)

Gailesiz baş yerin altında. (Aksoy 2013: 282)

Faydasız baş mezara yaraşır. (Aksoy 2013: 280)

Gülme komşuna gelir başına. (Aksoy 2013: 295)

Akıl yaşta değil baştadrr. (Aksoy 2013: 131)

Dazlayan daza düşer, kel başlı kıza düşer. (Aksoy 2013: 230)

Bir metafor olarak baş kelimesinin kullanıldığı atasözlerine bakıldığında; sağlk, iktidar, iyi gibi kavramlara karşılık olarak kullanıldığı görülebilmektedir. Elbette yukarı ve aşağıda olduğu gibi baş ile birlikte ayak da karşıtlık olarak karşımıza çıkmaktadır. Verilen son örnekte ise düş- fiilinin kullanılması dikkat çekicidir. Baş yukarıdadır ve buradaki düş- fiili sözlük anlam açısından denk gelmenin yanı sıra aşağıda olmayı da ifade etmektedir.

Düş- fiili yukarı-aşağı metaforlarında; sağlıksız, kederli, düşük statüyü ve düşkünlüğü ifade etmek için kullanılmıştır. Bu atasözleri arasında en bilineni "Düşenin dostu olmaz" (Aksoy 2013: 253) cümlesidir denilebilir. Burada maddi refahı kaybetmek için aşağıda olmak vurgulanmıştır. Düş- fiilinin maddi refah, keder ya da alçalmayı ifade eden başka kullanımları da bulunmaktadır:

Altın yere düşmek ile pul olmaz. (Aksoy 2013: 144)

Düştüğün yerden bir avuç toprakla kalk. (Aksoy 2013: 254)

Düştünse toprağa sarıl. (Aksoy 2013: 254)

El için kuyu kazan, evvela kendi düşer. (Aksoy 2013: 263)

Eşek bile düştüğü yere (çukura) bir daha düşmez. (Aksoy 2013: 274)

Gönül düştü bir boka, o da mis gibi koka. (Aksoy 2013: 290)

Her düşüş bir öğreniş. (Aksoy 2013: 307)

Kazma kuyuyu kendin düşersin. (Aksoy 2013: 353)

Kendi düşen ağlamaz. (Aksoy 2013: 358)

İyi olanın yukarıda olmayı ifade ettiği gibi kötü olanın aşağıda olduğunu ifade eden metaforik kullanımlarda atasözlerinde yer bulmaktadır. "Adamın yere bakanından, suyun sessiz (yavaş) akanından kork (Suyun yavaş akanından, insanın yere bakanından kork)" (Aksoy 2013: 117). Burada düşüncelerini açığa vurmayan kişinin tehlikeli olduğu yere bak- ile aşağıda olanı işaret ederek metafor şeklinde kullanılmıştır.

"Ağaca (taşa) çıkan keçinin dala bakan (ağaca çıan) oğlağı olur" (Aksoy 2013: 118). Bu atasözü de büyüklerini örnek almayı ögütlerken IYII OLAN YUKARIDADIR kuralından hareketle yukarıda olmayı göstermektedir. İyi olan yukarıda olduğu için "Kaçanı kovalamazlar, yıkılanı vurmazlar” (Aksoy 2013: 339) atasözünde yıkıl- fiili ile ifade edilen sağlıklı ve refah içerisinde olmayan kişidir.

Yukarıda olmak iyi, mutlu ve sağlıklı olmakla ilgili olduğu kadar hatta belki de daha fazla iktidar kavramı ile de ilgilidir. Atasözlerinde muktedir olan kişiler doğrudan ve dolaylı olarak yukarıda

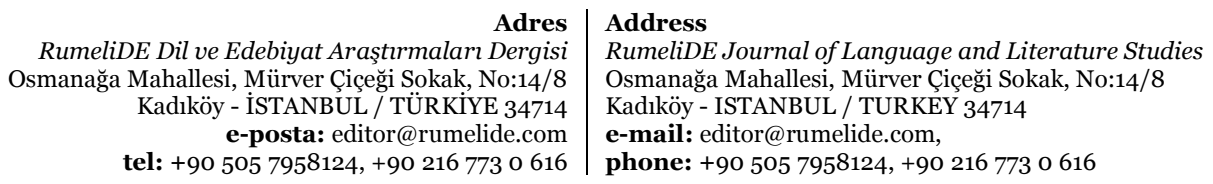


olmaklıkları ile vurgulanmışlardır. İktidar ve yukarı karşılığına geçmeden önce yukarıda olmanın bir sınırının olduğuna, sürekli olarak yukarıda olmanın mümkün olmadığını da belirtmek gerekmektedir. Yukarı aşağı metaforlarında "Düşmez kalkmaz bir Allah" (Aksoy 2013: 254) atasözü hem yukarıda olanın kudretini hem de sınırsız bir yukarıda olmanın mümkün olmadığını en net biçimde vurgulamaktadır. "Ağaç ne kadar uzasa göğe ermez" (Aksoy 2013: 119) atasözü de açılklamasında yer alan; "İnsan ne denli yükselirse yükseldin, bir yerde durur. Erişilmesi doğa yasalarına aykırı olan yüksekliğe çıamaz" cümlesi ile benzer bir durumu göstermektedir. Bu yükselmeyi ve/veya yukarıda olmayı iktidar ile dolaylı olarak ilişkilendiren "Ağaç yaşken eğilir" (Aksoy 2013: 119) sözü ise bir merhaleyi geçerek yukarıya ulaşanın muktedir olmasını vurgulamaktadır.

"Alçacık eşeğe herkes biner" (Aksoy 2013: 134), "Alçak yer yiğidi hor gösterir" (Aksoy 2013: 135), "Eşeği dama çıkaran yine kendi indirir" (Aksoy 2013: 273), "Alçak yerde tepecik kendisini dağ sanır" (Aksoy 2013: 135) atasözleri de güçsüz ve muktedir olmayanın aşağıda olduğuna diğer örnekler olarak saylabilir.

Atasözlerinde iktidar ya da yüksek statü sahibi olanın yukarıda olması zaman zaman unvanlarla da belirtilmiştir. Yukarıda anne-baba yukarıda olan örnek alınması gereken aile bireyleri olarak yer almıştı. Bunların yanı sıra padişah, ulular ve şah kelimeleri de YUKARIDA olan statü göstergeleridir:

Ahali isterse padişahı tahttan indirir. (Aksoy 2013: 125)

Mazlumun ahı, indirir şahı (yerde kalmaz). (Aksoy 2013: 388)

Ulular köprü olsa basıp geçme. (Aksoy 2013: 452)

Ulu sözü dinlemeyen, uyuyakalır. (Aksoy 2013: 453)

Doğrudan kişi unvanı belirtmenin yanı sıra tahta çı- birleşik fiili ile hem bir statü hem de statü sahibi olmak için yukarıda olmanın gerektiği de atasözlerinde yer bulmuştur: "Gelin altın taht (kürsü) getirmiş, çıkmış (üstüne) kendisi oturmuş. (Aksoy 2013: 285)

Yukarı ve aşağı kavramları söz konusu olduğunda gök ve gökyüzü de kullanılan metaforlardan biridir.

Göğe direk, denize kapak olmaz. (Aksoy 2013: 289)

Gökten ne yağdı da (yağar ki) yer kabul etmedi (etmesin)? (Aksoy 2013: 289)

Gökten yere yağar, yerden göğe değil. (Varlıklar yoksullara, güçlüler güçsüzlere yardım eder; tersi düşünülemez). (Aksoy 2013: 289)

Gökyüzünde düğün var deseler, kadınlar merdiven kurmaya kalkar. (Aksoy 2013: 289)

Gönülsüz namaz göğe (göklere) ağmaz. (Aksoy 2013: 291)

Kavak uzaya uzaya göğe yetmez. (Aksoy 2013: 350)

Yukarı aşağı metaforlarının içerisinde tüm bu anlatılanlarla çelişen bir atasözü ise dikkat çekmektedir. "Alçak yerde yatma sel alır, yüksek yerde yatma yel alır" (Aksoy 2013: 135). Aksoy bu atasözünün açıklamasını; "İnsan kendi durumuna uygun bir yaşayış sürmeli, arkadaşlarını ona göre seçmelidir. Çok aşağı yaşayış koşulları da çok yüksek yaşayış koşulları da kendisine zarar verir” şeklinde yapmaktadır. Burada aşağı ve yukarı dışında ortada kalmak gibi bir seçenek de vurgulanmıştır. Ayrıca atasözünün açıklamasında "çok aşağı" ve "çok yukarı" gibi derece bildiren ifadelerin kullanılması yukarı ve aşağının zihnimizdeki iyi ve kötü algısını göstermesi bakımından önemlidir.

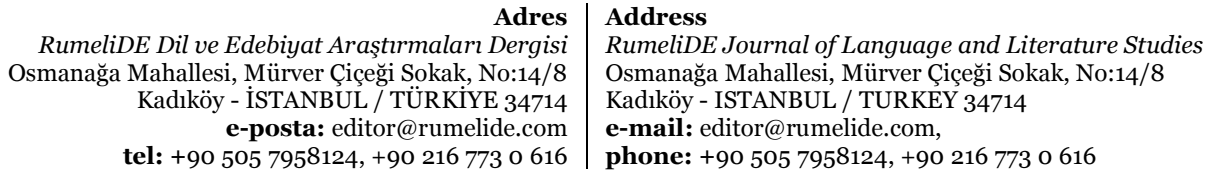

tel: +90 505 7958124, +90 2167730616 
Yukarıda verilen örneklerde AŞAĞIDA olan metafor örneklerinde sağlıksız, kederli, düşkün olarak gösterilen atasözleri örnekleri sıralanmıştı. Aşağıda olmak durumundan iyi, mutlu ve sağlıklı bir duruma gelebilmek için çabalamak gerektiğinin önemini vurgulayan atasözleri örnekleri de bulunmaktadır. "Eşek çamura çökerse sahibinden gayretlisi olmaz" (Aksoy 2013: 274), "Kalkacağın yere oturma" (Aksoy 2013: 342) atasözleri bu açıdan yukarıda olmanın iyi olduğunu vurgularken ayağa kalkabilmek için nasihat de etmektedir. "Alçak uçan yüce konar, yüce uçan alçak konar" (Aksoy 2013: 135) atasözü iktidar sahibi olmamasına rağmen kendisini başkasından üstün gören kişilerin yerinin AŞAĞIDA olduğuna dikkat çekmektedir. Tevazu sahibi ve alçak gönüllü olmak kendisi YUKARIDA olmasına rağmen aşağıdaymış gibi davranmak ise yukarıda da görüldüğü gibi takdir edilen bir tavırdır. "Boş çuval ayakta (dik) durmaz" (Aksoy 2013: 204) ve "boş başak dik durur" (Aksoy 2013: 204) atasözleri ilk bakışta birbirleri ile çelişkili gözükmektedir. Burada YUKARIDA olanın iyi, mutlu, sağlıklı ve muktedir olması kendi ağırlı̆̆ı ile bir tutularak örneklenmiştir. "Ağaç meyvesi olunca başını aşağı salar" (Aksoy 2013: 119) atasözü her iki cümleyi de kapsayan bir şekilde erdemli ve bilgili birinin kimseye yüksekten bakmayacağını ve alçakgönüllü olacağını belirtmektedir.

"Et ne kadar arık olsa, ekmek üstünde yaraşır" (Aksoy 2013: 277) atasözü açıklaması; ilgili görgülü kişiye, iş başında ve zengin olmasa bile bilgisiz, görgüsüz kişilerin üstünde bir yer yakışır şeklinde yapılmıştır. Açıklamada da üstte, yukarıda olmak vurgulanmıştır. Bu çabalamanın yansıtıldığı bir diğer atasözü ise, "Allah uçamayan kuşa alçacık dal verir" (Aksoy 2013: 140) şeklindedir. "Akıl akıldan üstündür” (Aksoy 2013: 128) atasözü de yine gayreti gösteren ve üstte, yukarıda olanın iyi olduğunun vurgulandığı örneklerden biridir.

Yukarı ve alçak metaforlarında son olarak; "Eğilen baş kesilmez" (Aksoy 2013: 257), "Eğilen boynu vurmazlar" (Yurtbaşı 2012: 108) ve "Eğilemeyen başın ayağı öpülür" (Yurtbaşı 2012: 108) atasözlerini ele almak gerekmektedir. Burada yukarıda olmak iki farklı şekilde ele alınmıştır. Bunlardan ilki bir şeyden aman dileyen, pişman olan kişinin YUKARIDA olmasına rağmen boynunu eğerek kudretini yok saymasıdır. Buradaki her iki örnek de iktidar ve yönelim metaforları açısından çarpıcı örneklerdir. Diğer örnekte ise kendi isteği ile değil zorla bir kişinin kudretini kırmak için AŞAĞI doğru çekmek söz konusudur. Bu durum yine metaforik bir ifade olan "dik durmak" ile açıklanabilir. Haksızlıklara karşı eğilmeyi yani aşağıda olmayı reddeden kişi yukarıda durduğu için daha da yüceltilmektedir.

Türk atasözleri içerisinde özellikle yukarı-aşağı yönelimli metaforların sayısı diğer yönelim metaforlarına göre sayıca fazladır. Söz konusu yapıdaki metaforlarda yukarıda olan şeyler olumlu aşağıda olan şeyler ise olumsuz anlam alanı içerisindedir. Bu bakış açısı Türk kültürü ile de sınırlı değildir. "İnsanın dünyadaki fiziksel durumunun tüm insanlık için aynı olduğu görüşüyle" (Yıldızlı 2017: 1493) aynı durumun evrensel olduğu bilinmektedir. Yukarı-aşağı yönelimli metaforlarda en aşağıyı gösteren atasözü ise "Kavanoz dipli dünya" (Aksoy 2013: 350) örneğidir. Hayatın ve dünyanın bilinmezliği kavanoz ve dip kelimeleri ile işaret edilmiştir. Aşağıda olanın kötü olduğu önermesi inceleme bölümünde özellikle mezar, kuyu, kaz- gibi metaforik ifadelerle dile getirilmişti. Burada İslamiyet etkisi açık biçimde görülebilmektedir. Ölü bedenler gömüldüğü için, hayatın bitişi, sağlıklı olma durumunun son bulması AŞAĞI olanı mezar ile somutlaştırmaktadır. Bu sebeple, IYYI OLAN YUKARIDA olduğu için kötü olanın da yükselebilmesi beklenemez. "Haramın binası olmaz" (Aksoy 2013: 302) atasözünde dinin etkisi haramın KÖTÜ olduğundan YUKARIDA olamayacağı gerçeğiyle aktarılmıştır. Lakoff ve Johnson da yönelim metaforlarının hem fizikî hem de kültürel temelleri olduğundan söz etmiştir. "Metafor, yalnızca tecrübe temeli dolayısıyla bir kavramı anlamanın aracı olarak hizmet edebilir" (Lakoff-Johnson 2003: 45). Din burada hem düşünce dünyasında hem de dilde

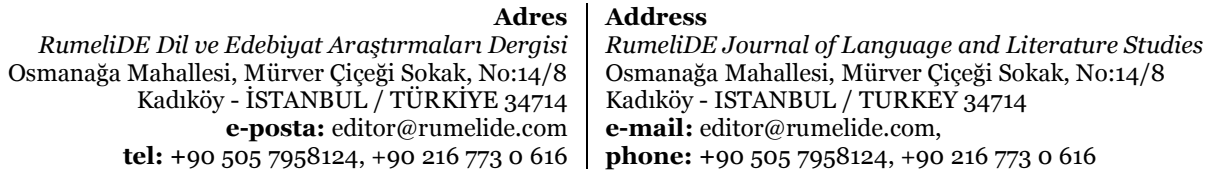

RumeliDE Dil ve Edebiyat Arassturmaları Dergisi tel: +90 $5057958124,+902167730616$
Address

e-mail: editor@rumelide.com

phone: +90 5057958124, +90 2167730616 
doğrudan karşllık bulan bir alan olarak büyük etki unsurudur. Örneğin; "Allah sağ eli sol ele muhtaç etmesin” atasözünde muhtaç olmaması gerekenin sağ el olması normunu din belirlemektedir.

\section{İleri-geri metaforları}

İleri-geri ve/veya ön-arka metaforları yönelim metaforları içerisinde yukarı-aşağı metaforları ile çok yakın ilişki içerisindedir. Her ne kadar yukarı aşağı metaforları dikey ileri geri metaforları yatay bir düzlem ile açıklanabilse de zaman zaman birbirinden ayırt etmek oldukça güçtür. Lakoff ve Johnson İLERIDE olan metaforların fiziksel temelini de tarif etmektedir. "Normal olarak gözlerimiz hareket ettiğimiz istikamete (ileriye, öne doğru) bakar. Bir nesne bir kişiye yaklaştıkça (yahut bir kişi bir nesneye yaklaştıkça), nesne daha büyük görünür. Zemin sabit bir şey olarak algılandığı için, nesnenin üst kısmı kişinin görüş menzilinde yukarı doğru hareket ediyormuş gibi görünür” (Lakoff-Johnson 2005: 43). Bu fiziksel temel açıklaması yukarı-aşağı ve ileri-geri metaforlarının neden birbiri ile karıştırılabileceğini de göstermektedir. Kişinin bir şeyle arasındaki mesafe azaldıkça karşıda olan, yukarıda olan halini alabilmektedir.

Tek başına ileri geri metaforlarını ele alırken ön-arka kavramlarını da bu başlık altında değerlendirmek gerekmektedir. Fiziksel olarak ileride olan önde, geride olan ise arkadadır. Yönelim metaforlarında kişinin uzay-mekân algısının yansıdı̆̆ı giriş bölümünde belirtilmişti. Burada kişinin kendisini merkeze aldığını görmek çok açıktır. Bu durumun sebebi ise Türkçedeki hareket bildiren bazı fiillerin kılınış özelliği olarak yön de bildirmesidir. Bilindiği gibi kılınış; fiillerin ontolojik olarak taşıdıkları ve sonradan değiştirilemez özellikleridir. Ana dili konuşurları dili edinirken fiillerin anlamları ile kılınışlarını da edinmektedirler. Bu sebeple bir bilgi olarak ya da fiilin anlamı olmasa da insan zihnindeki sözlükten bir fiili seçerken kılınışına göre seçmektedir. Bu durum özellikle, aynı kavram alanındaki sözcükler için geçerlidir. Örneğin; gel- ve git- fiillerinin sözlük anlamında "ulaşmak" (sozluk.gov.tr) yer almaktadır. Bu iki sözcüğü birbirinden ayıran ise konuşurun kendisini merkeze alarak ulaşmayı ifade ederken kendisine doğru olan ulaşma için gel- kendisinden uzaklaşan bir ulaşma için ise git- fiilini tercih etmesidir. Yönelim metaforlarında da ileri ve geri yönelimi ifade edilirken gel- ve git- fiilleri sıklıkla kullanılmıştır. Bu durum bir veri olarak nelerin daha yakın ya da uzak olduğunu da göstermektedir. Elbette yönün ne tarafa doğru olduğu seçilen merkez açısından da açılayıcıdır.

Ağır git ki yol alasın. (Aksoy 2013: 121)

Gel demek kolay ama git demek güçtür. (Aksoy 2013: 284)

Gel denilen yere gitmeye ar eyleme; gelme denilen yere gidip yerini dar eyleme. (Aksoy 2013: 284)

Geldik yüze, çıktık düze. (Aksoy 2013: 285)

Gelen geçer, konan göçer. (Aksoy 2013: 285)

Gelen gideni aratır. (Aksoy 2013: 285)

Gelene git denilmez. (Aksoy 2013: 285)

Gelen gidene rahmet okutur. (Aksoy 2013: 135)

Giden gelse dedem gelirdi. (Aksoy 2013: 288)

Gidip de gelmemek var, gelip de görmemek (bulmamak) var. (Aksoy 2013: 293)

Gidilmeyen yer senin olmaz (değildir). (Aksoy 2013: 288)

Görüldüğü gibi git- ve gel- fiilleri ile kurulan metaforik atasözlerinde mesafe bir mihenk taşı olarak yer almaktadır. Hedef olarak belirlenen nokta uzaklaştıkça ileride ya da uzakta olanın kötü olduğu anlamı

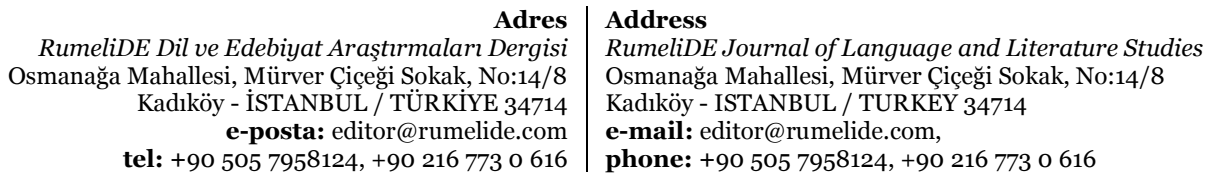


çlkmaktadır. Bunun en net örneği ölümün bir yolculuk olarak görülmesidir. Bu yolculuk tek taraflı olduğu için "giden gelse dedem gelirdi" atasözü en uzak mesafenin imkansızlığını ifade etmektedir.

"Kıbleden geldi kışımız, Allah’a kaldı işimiz" (Aksoy 2013: 359) atasözünde ise net bir yer ismi ile yönelim metaforu ifade edilmiştir. Buradaki ifade metaforik olsa da coğrafî bir gerçekliği de belirtmektedir. Kış afetleri güneyden gelmeye başlarsa, çok azgın bir mevsim geçirilecek demektir. Güneyden bir nokta olarak "kıble" merkeze alınmıştır. Metaforlarda fiziksel temellerin, deneyimlerin ve kültürel faktörlerin belirleyici olduğu bilinmektedir. Burada ileri ve geri metaforu gel- fiili ile ifade edilmektedir. Ancak güney yönünün kıble kelimesi ile yansıtılması dinî ve kültürel arka planı da göstermektedir.

Yukarıda ileri-geri metaforlarında söz konusu kelimelerle aynı kavram alanından olan ön ve arka sözcüklerinin de dahil edilmesi gerektiği söylenmişti. Bu noktada hem ileri-geri hem de ön-arka metaforları birlikte sunulacaktır. Tıpkı ileri-geri metaforlarında gel- ve git- fillerinde yakın mesafenin IYİ uzak olanın ise KÖTÜ olması gibi, ön-arka kavramlaştırmasında da ÖNDE OLAN İİ ARKADA OLAN KÖTÜ argümanı görülebilmektedir. Elbette burada iyi ve kötü kelimeleri olumlu-olumsuz kavram alanında genel bir ifade olarak verilmektedir. Aşağıda verilen her bir atasözünde ÖNDE OLAN BAŞARILI-SAĞLIKLI-HUZURLU, ARKADA (GERIDE) OLAN MUTSUZ- KORUNMASIZ-HASTATEHLİKELİ olabildiği de yer almaktadır.

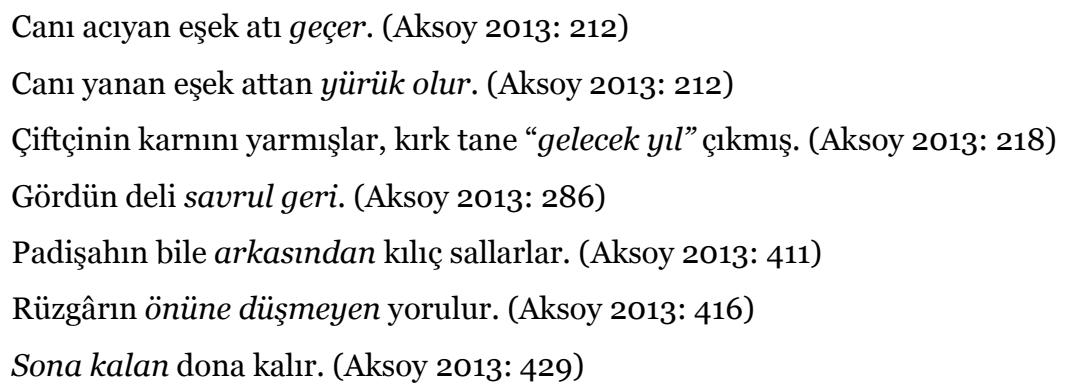

Geride olanın olumsuz bir yargıya sahip olmasına "Atılan ok geri dönmez" (Aksoy 2013: 161) atasözü de örnek olarak gösterilebilir. Bir işe kalkışmaktan vazgeçmek fikri bu atasözünde hem geri kelimesi hem de sön- fiili ile aktarılmıştır. Bu kelimelere ek olarak geçmiş olanın geride kaldığını düşünmek mümkündür. Bu varsayım doğru kabul edildiğinde yönelim metaforlarının sadece mesafe ile değil zaman ile de ilgili olduğu söylenebilir. "Geçmişe mazi, yenmişe kuzu derler" (Aksoy 2013: 284) atasözündeki yönelim metaforu zamanı da ifade etmektedir.

Yakın ve uzak metaforlarına geçmeden önce son olarak bir fiziksel eylemin yönelim metaforu olarak kullanıldı̆̆ı bir örneği sunmak mümkündür. "Ayağını yorganına göre uzat” (Aksoy 2013: 166) atasözünde kullanılan uzat- eylemi ileriyi ve önde doğru olan hareketi ifade eden bir fiildir. Bu yönüyle ileriye doğru yapılan bu hareket, önde olan geleceğin düşünülmesi ve göz ardı edilmemesini vurgulamaktadir.

\section{Yakın ve uzak metaforları}

Bu başlık altında yakın ve uzak kavram alanındaki metaforlar ele alınacaktır. Bu tip metaforların yukarıdaki ileri-geri ve ön-arka metaforları ile de ilgili olduğunu tekrar vurgulamak gerekmektedir. Örneğin yukarıdaki gel- ve git- fiilleri ile ilgili verilen örneklere benzer şekilde kurgulanmış "Davulun sesi uzaktan hoş gelir” (Aksoy 2013: 229), “Aşıka Bağdat uzak (rrak) değil (gelmez)” atasözlerinde her

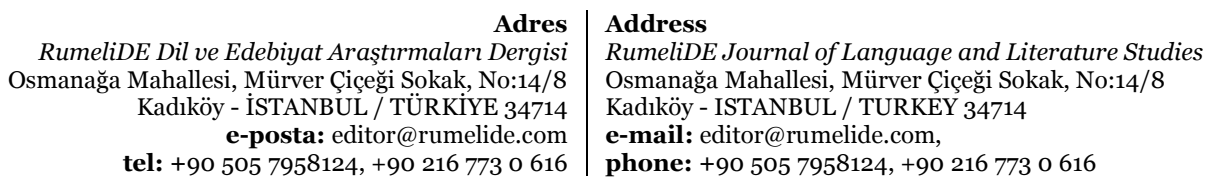


iki yönelim metaforunu da görmek mümkündür. Yakın ve uzak metaforları sadece ileri-geri kavramları ile değil yukarı ve aşağı metaforları ile de oldukça yakın bir alanda durmaktadır.

Burada önemli olan yakın ve uzağın neyi ifade ettiğidir. Yönelim metaforlarının bu kısmında YAKIN OLAN IYYIDİR, UZAK OLAN KÖTÜDÜR yargısını görmek mümkündür.

Ağaç düşse de yakınına yaslanır. (Aksoy 2013: 118)

Göçtük yurdun kadri konduk yurtta bilinir. (Aksoy 2013: 288)

Görünen dağın (köyün) uză̆ı olmaz. (Aksoy 2013: 292)

Görünen köy kllavuz istemez. (Aksoy 2013: 293)

Gözden rrak (uzak) olan gönülden de rrak (uzak) olur. (Aksoy 2013: 293)

Göz gördüğünü (ağız yediğini) ister. (Aksoy 2013: 293)

Göz görmeyince gönül katlanır. (Aksoy 2013: 293)

Göz görür, gönül ister (çeker). (Aksoy 2013: 293)

İştah dişin dibindedir. (Aksoy 2013: 331)

Tarlanın (malın) iyisi suya yakın, daha iyisi eve yakn. (Aksoy 2013: 442)

Yakın ve uzak belirten bu metaforik atasözlerinde görme organı olan gözün merkeze alındığı görülmektedir. Bazı atasözlerinde doğrudan yakın ve uzak kelimeleri kullanılırken bazılarında ise gözden trak, gözün görmesi bir şeyin ya da yerin görünen olması mesafeyi belirtmektedir. Gözün gördüğü mesafe insanın ihata alanında kabul edilerek yakın sayılmıştır. Bu yakınlık da YAKIN OLAN IYYIDİR yargısını güçlendirmektedir.

Burada yakın olanın iyiliği vurgulanırken mekân ve yönelim dışında başka başlıkları da konu etmek mümkündür. Yakında olanın karlı olması, az ve çok kavram alanı içerisinde ele alınabilecek kavramlardan biridir. Her ne kadar az ve çok kavram alanı bir başlık olarak başka bir çalışmanın konusu olsa da yönelim metaforları ile kesişen bir atasözüne burada yer vermek doğru olacaktır. "Kısmet gökten zembille inmez" (Aksoy 2013: 361) atasözünde bir yönelim metaforu olarak yukarı ve aşağının kullanıldığı görülebilmektedir. Bu metafor aynı zamanda yakında olanın iyi ya da karlı olduğunu en uzağı işaret ederek vurgulamaktadır. İyi ve karlı olanı uzaktan beklemeye gerek yoktur. Onu yukarıdan beklemek yersizdir zira iyi olan yakındır. Bu atasözü ile çelişse de "Kısmet ise gelir Hint'ten, Yemen'den, kısmet değilse ne gelir elden" cümlesi de yakın ve uzak yönelim metaforları bağlamında değerlendirilebilir. Burada vurgulanmak istenen tıpkı yukarı ve aşağı metaforlarında yer alan "baş eğ-“ fiilinin iki farklı anlam alanı ile kullanılmasıdır. Herhangi bir şey olacaksa bu durum uzak veya yakın olma ile şartlı değildir.

İleri-geri metaforlarında beden dışında bir canlının yaşadığı alanın da merkeze alındığını görmek mümkündür. Örneğin; "Gelin eşikte, oğlan beşikte" (Aksoy 2013: 286) atasözünde evin alanında sınır sayılabilecek eşik ile evlilik ifade edilmiştir. Gelinin eşikte yani YAKIN olması ve sınırdan içeri girmesi doğurması beklenen çocuğun müjdecisidir. Böylelikle YAKINDA OLAN IYYIDİR argümanı bir kez daha dile getirilmiş olmaktadır. Atasözlerinde insanın sınırı olarak evin gösterilmesi gibi canlılardan ağaç için de kök sınır ve yakın olarak sunulmuşstur. YAKIN OLAN IYİDİR argümanı burada tezat gibi gözükse de bir şeyin mahvolması için yakında olanın çökertilmesi gerekmektedir. Yakında ve dolayısıyla iyi ve sağlıklı olanın çökertilmesi elbette çok zordur. "Burun yüzden düşmez" (Aksoy 2013: 206) atasözünde de bir kimsenin yakınında olan kişi ne kadar uygunsuz, yakışıksız iş yaparsa yapsın kendisiyle olan yakınlık ilişkisinin bozulamayacağı ifade edilmektedir. Yakında olan aynı zamanda

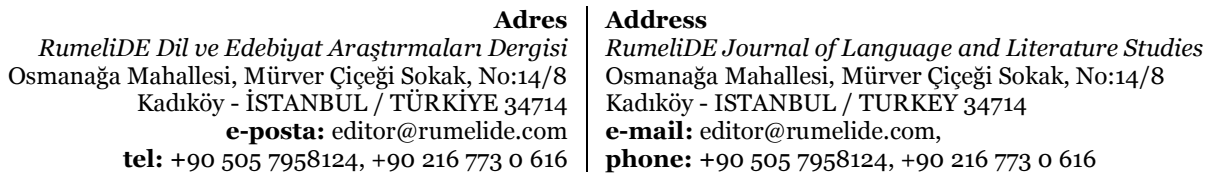


korunaklı bir alanın da içine dahil olmaktadır. Tam da bu sebeple YAKIN OLAN IYYIDİR argümanının yanı sıra YAKIN OLAN DOSTTUR-UZAK OLAN DÜŞMANDIR yaklaşımını ifade eden atasözleri ile sıklıkla karşılaşılabilmektedir. Burada YAKIN ve DOST olanın kardeş, komşu, karı-koca gibi akrabalık adları ile doğrudan ifade edildiği örnekler de bulunmaktadır. "Kardeşten karın yakın, kulaktan burun yakın" (Aksoy 2013: 345), "Komşu kızı almak, kalaylı kaptan su içmek gibidir", "Komşu komşunun külüne muhtaçtır" (Aksoy 2013: 368) gibi atasözleri yakında olanın DOST ve IYYI olduğuna doğrudan akrabalık terimleri ile karşlayan örneklerdir. Yakın olanın DOST olduğuna ve zarar vermeyeceğini, verilemeyeceğini gösteren en çarpıcı örnek ise vahşi bir hayvan olan kurt metaforu ile yapılmıştır. "Kurt komşusunu yemez" (Aksoy 2013: 365) atasözünde kurdun bile komşusuna; dost ve yakın olduğu için zarar veremeyeceği çarpıcı olarak sunulmuştur.

Atasözlerindeki yönelim metaforlarında sadece yakın olan değil uzak durulması gerekenler de vurgulanmıştır. Bu mesafe ifade eden atasözlerinde; kimlerden ya da nelerden uzak durulması gerektiği ve uzakta olanın muhafazalı alandan çıkmış olacağı için zarar görebileceğini görmek mümkündür. uzak durulması gerekenlerin başında YAKI OLAN DOSTTUR, UZAK OLAN DÜŞMANDIR savını destekleyen düşman gelmektedir. "Düşmana yarak (silah) gerek, ya düşmandan rrak gerek” (Aksoy 2013: 253) atasözü tam olarak bu durumu ifade etmektedir. Ayrıca;

"Çam ağacından ağıl olmaz, el çocuğundan oğul olmaz",

Çarşı iti ev beklemez (Aksoy 2013: 216),

Gezen ayağa taş değer (Aksoy 2013: 287),

Her gün gezen kırda, bir gün uğrar kurda (Aksoy 2013: 307),

Yakın (hayırlı) dost (komşu) hayırsız hısımdan (akrabadan) yeğdir (iyidir) (Aksoy 2013: 464)

Atasözleri dışarıda olanın, el olanın ve sınır alandan çıkılmasının muhafazayı kaybettireceğini metaforik olarak ifade etmektedir. Yakınlı̆̆ın fiziksel temeldeki önemi, örnek olarak verilen son atasözünde kan bağı olan akrabadansa, merkeze YAKIN olan komşunun HAYIRLI ve DOST olarak görülmesi ile de ortaya çıkmaktadır. Elbette atasözlerindeki mesafe ve yönelim metaforlarında ilerigeri ile aynı kavram alanında ön-arka ve öte-beri yönelimlerinden de söz etmek gerekmektedir. "Duvarın beri yüzü beri, öte yüzü öte" (Aksoy 2013: 249) atasözünde; hısımlar, dostlar ne denli yakın yerde otururlarsa otursunlar birbirlerinin özel yaşantısını bilmezler ve buna karışmazlar anlamı vardır. $\mathrm{Bu}$ anlam da yukarıda söz edilen iç-dış kavramları bağlamındaki sınırın ne kadar da keskin ve korunaklı olduğunu göstermektedir. Yine "Akçanın iyisi kesede duran, bahçanın iyisi eve yakın olan" (Aksoy 2013: 127) atasözünde de bu sınırı bahça kelimesi ile görmek mümkündür. Burada bahçanın bittiği yer DIŞARIDA olandır ve elbette DIŞARIDA OLAN KÖTÜDÜR.

Atasözlerindeki yakın-uzak metaforunda her zaman somut mesafe belirleyicileri kullanılmamıştır. Zaman kavramı etrafında ele alınabilecek bazı atasözlerinde ise zamanın UZAK durumundan YAKIN hale gelmesi bir müjde olarak görülmüştür. "Getir bana Hıdırellez’i, göstereyim sana yazı" (Aksoy 2013: 287) atasözünde Hıdırellez’in yakın duruma gelmesi yazın da habercisi sayılmıştır. Buradaki gibi yaklaşan ve dolayısıyla sınır alanın içine giren atasözlerini içeri-dışarı yönelimli kabul etmek yanlış olmayacaktır.

Kırgız atasözlerindeki yönelim metaforları üzerine yapılmış bir çalışmada (Akın 2017) özellikle ön-arka yönelimli metaforların diğer yönelim metaforlarına göre daha fazla kullanılmış olduğu görülmektedir. Burada ele alınan atasözlerinde ileri-geri, ön-arka metaforlarında sadece yönün değil aynı zamanda zamanın da ifade edildiği görülmektedir. Doğrudan yön adının geçtiği atasözleri ise oldukça sınırlıdır.

\footnotetext{
\begin{tabular}{r|l} 
Adres & Address \\
RumeliDE Dil ve Edebiyat Araşttrmaları Dergisi & RumeliDE Journal of Language and Literature Studies
\end{tabular} Osmanağa Mahallesi, Mürver Çiçeği Sokak, No:14/8 Osmanağa Mahallesi, Mürver Çiçeği Sokak, No:14/8 Kadıköy - İSTANBUL / TÜRKIYE 34714 Kadıköy - ISTANBUL / TURKEY 34714 e-posta: editor@rumelide.com e-mail: editor@rumelide.com, tel: +90 505 7958124, +90 2167730616 phone: +90 505 7958124, +90 2167730616
} 
Ön-arka metaforlarında zaman kavramının kastedildiği kullanımlar, doğrudan yön bildiren atasözlerinden fazladır. $\mathrm{Bu}$ atasözlerinde göre GELECEK ÖNDE/ILLERIDE, GEÇMIŞ ARKADA/GERIDE bulunmaktadır. Tam da bu sebeple yakın-uzak yönelimli metaforlarda da zaman kavramını işaret eden kullanımlar görülmektedir. Yukarıda verilen örneklere ek olarak; "Bugünkü işi yarına bırakma" ya da "Bugünkü tavuk yarınki kazdan iyidir" (Aksoy 2013: 206) gibi atasözlerinde hem uzak-yakın hem de ileri-geri yönelimleri ile zaman kavramının konu edildiği görülmektedir.

\section{İçeri ve dışarı metaforları}

Yukarıda verilen yakın-uzak, ön-arka kavramlarını kapsayan yönelim metaforlu atasözlerinde, sınır alan ve yakınlığın mesafesi üzerinde de iç-ve dış metaforları sunulmuştu. Ancak doğrudan çık- ve girfilleri ile işaretlenen atasözlerindeki yönelimi ayrıca ele almak da mümkündür. "Dayak cennetten çıkmıştır” (Aksoy 2013: 229) atasözünde dayak gibi olumsuz bir eylemin bazı durumlarda gerekli olduğu gösterilmek için cennetten geldiği vurgulanarak IYYI olduğu gösterilmek istenmiştir. "Fare çıtığı deliği bilir" (Aksoy 2013: 280), "Evden bir ölü çıkacak demişler, herkes hizmetçinin yüzüne bakmış" (Aksoy 2013: 297) ve "Gelin girmedik ev olur, ölüm girmedik ev olmaz" (Aksoy 2013: 286) atasözlerinde de doğrudan kılınışında yönelim olan fiiller kullanılarak IYYi/SAĞLIKLI OLAN YAKINDA/IÇERIDE VE KÖTÜ/HASTALIKLI OLAN UZAKTA/DIŞARIDADIR argümanı işaretlenmiştir.

Bazı atasözlerinde ise doğrudan gir- ve çı- fiili kullanılmasa da kullanılan başka eylemlerle yönelim metaforik olarak ifade edilmiştir. Kullanılan bu fiiller arasında slŭ-, koy-ve sok-kelimelerini saymak mümkündür. Yukarıda sayılan sığ-, koy- ve sok-fiillerini kullanabilmek için bir nesneye ihtiyaç vardır. Bir şeyin içine bir şeyi sığdırabilirsiniz. Nitekim "Mızrak çuvala sığmaz” (Aksoy 2013: 390) atasözünde çuval içeri-dışarı yönelimi için kullanılmış bir eşyadır. "Bülbülü altın kafese koymuşlar ha vatanım demiş” (Aksoy 2013: 208) atasözünde de kafes iç-dış bağlamında yönelim bildiren bir sınır alanıdır. Son olarak sok- fiilinin kullanıldı̆̆ı, "Her deliğe (taşın altına) elini sokma ya yılan çıkar ya çıyan" (Aksoy 2013: 307) atasözü yer almaktadır. Bu atasözünde de delik ve/veya taş sözcükleri içeri-dışarı bağlamında metaforik olarak kullanılmıştır.

\section{Sonuç}

Lakoff ve Jonhson metaforları tanımlarken bir şeyi başka bir şeye göre düşünme sorunu olarak tanımlamışlardır (Lakoff-Johnson 2003: 12). Bu tanım üzerinden Türk atasözleri değerlendirildiğinde yönelim açısından sınırların ne kadar net olduğu görülen ilk sonuçtur. Özellikle yakın-uzak, iç-dış, ileri-geri yönelimlerinde metaforik olarak kullanılan isimler ve fiiller, kültürel olarak nelerin uzak ve dış olarak sayılabileceğini açıcça göstermektedir. Ev, tarla, bahçe gibi insanın habitusunu gösteren yerler, IYYI, SAĞLIKLI, HUZURLU olanın de yurdudur. Bunu dışında kalan yerler ise KÖTÜ, SAĞLIKSIZ ve HUZURSUZ olarak görülmektedir. "Sonradan gelenin evi uç, tarlası kıraç olur" (Aksoy 2013: 431) atasözünde bu aidiyetin önemi vurgulanmakla kalmaz, aynı zamanda söz konusu habitusun ne kadar korunaklı olduğunu da gösterir. Burada atasözleri her ne kadar sadece yönelim metaforları açısından ele alınmış olsa da cinsiyetçiliğin açıkça görülebildiği örnekler de gözden kaçmamaktadır. Yukarıda metin içerisinde gelin, damat gibi sonradan akrabalık ilişkilerine dahil olan ve ailede İÇERİde olduktan sonra İİ, HUZURLU, SAĞLIKLI kabul edilen örnekler incelenmişti. Bir başka atasözünde ise "sonradan gelen"in tam olarak sınır alandan içeri giremediğini cinsiyetçi bir dille göstermektedir. "Karı (kadın) malı kapı mandalı (hamam tokmağı)" (Aksoy 2013: 346) atasözünde kapının mandalı ifadesi evin tam da sınırında ama dışında olanı ifade etmektedir.

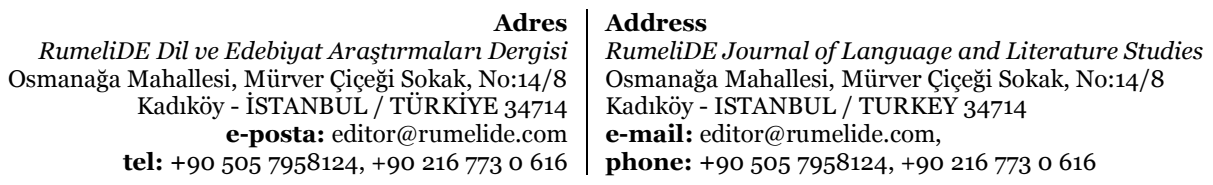


“İnsan, içinde yaşadığı gerçekliği ancak metaforlar vasıtasıyla ve metaforik olarak inşa edebilir" (Çakır 2020: 127). Bu gerçekliğin yansımasını atasözlerinde bulmak mümkündür. Burada yapılan incelemede YUKARIDA OLAN SAĞLIKLIDIR, AŞAĞIDA OLAN SAĞLIKSIZDIR önermesinin atasözlerinde karşılık bulduğunu söylemek mümkündür. Yukarıda incelenen ve örneklenen atasözlerinde olduğu gibi, "Yatanın yürüyene borcu var" ve "Yatan öküze yem yok" (Aksoy 2013: 469) örnekleri de net biçimde sağlıklı olmanın ayakta olan olduğunu göstermektedir. Yine yukarı-aşağı bağlamında sağlıklı olanın yukarıda olduğuna işaret eden "Taş altında olmasın da dağ ardında olsun" (Aksoy 2013: 313) atasözü de ölüm ve aşağı yönelimlerini birleştirmektedir. Metaforlar, "alışılmış kelimelere yeni manalar" (Özevren 2019: 75) kazandırmaktadır. Burada ele alınan tüm örneklerde bu durumu gözlemek mümkündür. Örneğin, yokuş kelimesi sözlük anlamının dışında atasözlerinde yukarı-aşağı yönelimli bir cümlede karşımıza çıkmaktadır. "Her inişin bir yokuşu (her yokuşun bir inişi) vardır" (Atasoy 2013: 308/313) cümlesinde metin içerisinde verilen örneklere paralel olarak, yukarı-aşağı yönelimlerinde yukarı kavramının olumlu, aşağı kavramının ise olumsuz bir algısı olduğunu bir arada vermektedir.

“Taş altında olmasın da dağ ardında olsun” (Atasoy 2003: 310) atasözünde ise bu çalışma kapsamındaki tüm yönelimleri adeta bir arada bulmak mümkündür. Başlangıçta yönelim metaforlarının uzay/mekân algısı ile ilgili olduğu söylenmişti. Bu algı sadece zihinsel değil kültürel ve fiziksel deneyimlerle oluşmaktadır. Kültürel deneyimlerin içerisinde; coğrafyanın etkili olduğu gelenekler, dinin belirleyiciliğini saymak mümkündür. Fizikî tecrübeler insanın kendisini merkeze alan ve sosyal bir varlık olarak kendisini evrende konumlandırdıktan sonra çevresini çizmesiyle oluşmaktadır. "Taş altında olmasın da dağ ardında olsun" atasözünde hem yukarı-aşağı hem iç-dış hem de yakın-uzak yönelimlerini bir arada görürken fiziki ve kültürel tecrübenin bir cümlede toplandığı özet bulunabilmektedir.

Bu durum aynı zamanda Türk atasözlerinde kategoriler ve yönelimler arasında bir geçiş olduğu sonucunun elde edilmesini de sağlamaktadır. Somuttan soyuta, yakından uzağa, içeriden dışarıya merkezli olarak üretilen atasözlerindeki bu tavır tüm canlıları kapsar niteliktedir. Atasözlerinin yönelimlerini tek tek ele alırken, bir yönelimin olması diğerini dışarıda bırakmamıştır. Birden fazla yönelimli atasözü dildeki göstergelerin ne kadar da iç içe geçtiğini göstermektedir.

Ayrıca incelemede bireyin kendisini, ailesini, evini, toprağını merkeze aldığı söylenmişti. Bu kavramların yanına bitki ve hayvan adlarının geçtiği atasözlerinin örneklerini de ekleyerek, Türk atasözlerinde insanın sadece kendisini değil kendi sınır alanındaki şeyleri merkez kabul ettiği sonucuna varmak mümkündür.

\section{Kaynakça}

Akın, C. (2017). Kırgız atasözlerinde yönelim metaforu kullanımı. Türk Dünyası Dil ve Edebiyat Dergisi, (44), 9-17.

Aksoy, Ö.A. (1988). Atasözleri, deyimler, Türk Dili Araştırmaları Yıllığı Belleten-1962 Ankara: TDK.

Aksoy, Ö. A. (2013). Atasözleri ve Deyimler Sözlüğü, İstanbul: İnkılap.

Amin T.G (2009). Conceptual metaphor meets conceptual change, Human Development, 52, (165197).

Aristoteles (2004). Poetika (Çev. İsmail Tunalı). İstanbul: Remzi.

Cerit, Y. (2008). Öğretmen Kavramı ile İlgili Metaforlara İlişkin Öğrenci, Öğretmen ve Yöneticilerin Görüşleri. Türk Eğitim Bilimleri Dergisi, (6):461- 522.

\begin{tabular}{|c|c|}
\hline Adres & Address \\
\hline RumeliDE Dil ve Edebiyat Araşttrmaları Dergisi & RumeliDE Journal of Language and Literature Studies \\
\hline manağa Mahallesi, Mürver Çiçeği Sokak, No:14/8 & Osmanağa Mahallesi, Mürver Çiçeği Sokak, No:14/8 \\
\hline Kadıköy - İSTANBUL / TÜRKIYE 34714 & Kadıköy - ISTANBUL / TURKEY 34714 \\
\hline e-posta: editor@rur & e-mail: editor@rumelide.com, \\
\hline $958124,+9$ & $8124,+902167730616$ \\
\hline
\end{tabular}


Çakır, M. Y. (2020). Yeni Uygur Atasözlerinin Yönelim Metaforları Açısından İncelenmesi, Uluslararası Uygur Araştırmaları Dergisi, Sayı: 2020/15, s. 126-140.

Johnson, D. W., \& Johnson, R. T. (1987). Learning together and alone: Cooperative, competitive, and individualistic learning (2nd ed.). Prentice-Hall, Inc.

Kıran, Z.- Kıran, A.. (2006). Dilbilime Giriş. Ankara: Seçkin.

Lakoff, George -Mark, Johnson (1980). The metaphorical structure of the human conceptual system, Cognitive Science, 4, 195-208

Lakoff, G. (1990). Some Empirical Results About The Nature of Concepts, UC Berkeley Previously Published Works, https://escholarship.org/uc/item/63v3h67m

Lakoff, G.-Mark, J. (2005). Metaforlar- Hayat, Anlam ve Dil (Çev. Gökhan Yavuz Demir), İstanbul: Paradigma.

Modell H- Modell M.D (2009). Metaphor-the beridge between feelings and knowledge, Psychoanalytic Inquiry A topical Journal for Mental Health Professionals, V.29-1 (6-11).

Özevren, M. (2019). Kutadgu Bilig'de “iyi olan yukarıda, kötü olan aşağıda metaforu” üzerine. RumeliDE Dil ve Edebiyat Araştırmaları Dergisi, RumeliDE 2019. Ö 5- II. Rumeli [Dil, Edebiyat, Çeviri] Sempozyumu Bildirileri, (69-76).

Sarı, C. (2016). Deyimlerde aşağı/ yukarı yönelim metaforu, Uluslararası Sosyal Araştırmalar Dergisi C. 9-S.44 (212-216).

Shinebourne, P.-Jonathan A. S. (2010). The communicative power of metaphors: An analysis and inter pretation of metaphors in account of the experience of addiction, Psychology and Psychotherapy: Theory, Research and Practice, V. 83-1, (59-73).

Yaylagül, Ö. (2010). "Divânu Lugâti't-Türk’te Yer Alan Atasözlerindeki Metaforlar", Millî Folklor, Yıl 22, Sayı 85 (113-121).

Yıldızlı, M. E. (2017). Yönelim metaforlu deyimlerin sinıflandırılması. Hitit Üniversitesi Sosyal Bilimler Enstitüsü Dergisi, Yıl 10, Sayl 2, Aralık 2017, (1489-1498).

Yurtbaşı M. (2012). Stnıflandırılmış Türk Atasözleri. İstanbul: Excellence Publishing.

https://sozluk.gov.tr/

RumeliDE Dil ve Edebiyat Araşttrmaları Dergisi Osmanağa Mahallesi, Mürver Ciçeği Sokak, No:14/8 Kadıköy - İSTANBUL / TÜRKIYE 34714 e-posta: editor@rumelide.com tel: +90 505 7958124, +90 2167730616
Address

RumeliDE Journal of Language and Literature Studies

Osmanağa Mahallesi, Mürver Çiçeği Sokak, No:14/8

Kadıköy - ISTANBUL / TURKEY 34714

e-mail: editor@rumelide.com,

phone: +90 505 7958124, +90 2167730616 